\title{
The Salivary Concentration of Chemical Elements in Response to Training Loads in Brazilian Jiu-Jitsu Athletes
}

\section{Concentração Salivar de Elementos Químicos em Resposta a Cargas de Treinamento em Atletas de Brazilian Jiu-Jitsu}

\author{
Aline Campos Zeffa*a; Flavia Campos ${ }^{\mathrm{b}}$; Braulio Henrique Magnani Branco ${ }^{\mathrm{c}}$; Leonardo Vidal Andreato ; \\ Avacir Casanova Andrello ${ }^{\text {; }}$ Solange de Paula Ramos ${ }^{\mathrm{e}}$ \\ ${ }^{a}$ Universidade Estadual de Londrina, Stricto Sensu Graduate Program in Dentistry. PR, Brasil. \\ bUniversidade Estadual de Londrina, Stricto Sensu Graduate Program in Physical Education. PR, Brasil. \\ 'Unicesumar. PR, Brasil. \\ dUniversidade Estadual do Amazonas. AM, Brasil. \\ ${ }^{\mathrm{e} U n i v e r s i d a d e ~ E s t a d u a l ~ d e ~ L o n d r i n a . ~ P R, ~ B r a s i l . ~}$ \\ *E-mail: aline-a-campos@hotmail.com
}

\begin{abstract}
The saliva analysis by Total Reflection X-Ray Fluorescence (TXRF) for monitoring training loads could be useful due to the ease of sample analysis and a large range of chemical elements can be detected. Twelve BJJ athletes were submitted to 7 weeks of training scheduled with high training loads (weeks 1 to 4) and tapering (weeks 5 to 7). Saliva samples were collected before (Pre), at week 4, and at week 8 (Post), to quantify chemical element concentrations by TXRF. The internal training load was monitored using the session rating of perceived exertion of session (RPE) method for physical and technical-tactical training sessions. All the saliva samples presented Phosphorus (P), Sulfur (S), Chlorine (Cl), Potassium (K), Calcium (Ca), Zinc (Zn), Bromine (Br), and Rubidium (Rb) at Pre, 4 weeks and Post time points. Salivary concentrations of $\mathrm{Cl}$, $\mathrm{K}$, Manganese $(\mathrm{Mn})$, Copper $(\mathrm{Cu}), \mathrm{Br}$, and $\mathrm{Rb}$ significantly decreased in 4 weeks $(\mathrm{p}<0.05)$; and $\mathrm{K}, \mathrm{Cu}$, and $\mathrm{Rb}$ concentration remained at low levels at Post $(\mathrm{p}<0.05)$. Medium to large Cohen's effect sizes for decrements in element concentrations from Pre to 4 weeks was observed for all the elements except $\mathrm{Zn}$. Reduced $\mathrm{S}$ concentration at 4 weeks was negatively correlated to high training load period ( $\mathrm{r}=-0.56, \mathrm{p}=0.05)$. The results suggest that BJJ training modulates salivary electrolyte composition and salivary $\mathrm{P}, \mathrm{S}$ and $\mathrm{Rb}$ are correlated with training loads in BJJ athletes.
\end{abstract}

Keywords: Ions. Martial Arts. Exercise. Biomarkers. Saliva.

\section{Resumo}

A análise de saliva por meio de Fluorescência de Raios-X de Reflexão Total (TXRF) para monitorar cargas de treinamento pode ser útil devido à facilidade de análise da amostra e a ampla variedade de elementos químicos detectados. Doze atletas de BJJ foram submetidos a 7 semanas de treinamento programado com altas cargas de treinamento (semanas 1 a 4) e polimento (semanas 5 a 7). Amostras de saliva foram coletadas antes (Pré), na semana 4 (Meio) e na semana 8 (Pós), para quantificar as concentrações dos elementos químicos por TXRF. A carga interna de treinamento foi monitorada por meio do método de percepção subjetiva de esforço da sessão (PSE) nas sessões de treinamento físico e técnico-tático. Todas as amostras de saliva apresentaram Fósforo (P), Enxofre (S), Cloro (Cl), Potássio (K), Cálcio (Ca), Zinco (Zn), Bromo (Br) e Rubídio (Rb) no momento Pré, 4 semanas e Pós. As concentrações salivares de Cl, K, Manganês (Mn), Cobre (Cu), Br e Rb diminuíram significativamente em 4 semanas ( $p<0,05$ ); e a concentração de $K$, Cu e Rb permaneceram em níveis baixos no Pós $(p<0,05)$. Os tamanhos de efeito de Cohen médio a grande para decréscimos nas concentrações de elementos, de Pré a 4 semanas, foram observados para todos os elementos, exceto para $\mathrm{Zn}$. A redução da concentração de $\mathrm{S}$ em 4 semanas foi negativamente correlacionada com o periodo de alta carga de treinamento $(r=-0,56, p=0,05)$. Os resultados sugerem que o treinamento de BJJ modula a composição eletrolitica salivar e o $P$, $S$ e Rb salivares estão correlacionados com as cargas de treinamento no BJJ.

Palavras-chave: Íons. Artes Marciais. Exercício. Biomarcadores. Saliva.

\section{Introduction}

Athletes at rest and under high physical efforts differently modulate the circulating, urinary, and salivary concentrations of several chemical elements ${ }^{1-5}$. This fluctuation in body fluid chemical content may be related to physical and metabolic demands (aerobic $\mathrm{x}$ anaerobic adaptations), oxidative stress, inflammatory status, nutritional strategies, and muscle damage $^{1,2,6,7}$. The trace elements and macroelements in the blood, urine, and tissues are altered by both acute physical exercise and training ${ }^{2,5,6,8}$. Thus, monitoring chemical element concentrations in biological fluids may be useful to monitor metabolic profile, physical recovery, and the risk of underperformance in athletes ${ }^{2,6,7}$. Therefore, saliva sampling may be useful since it is an easy sampled and non-invasive method, allowing multiple collections without requiring immediate sample preparation.

Trace elements and macroelements have been investigated in several individuals and team sports to monitor physiological adaptations and nutritional demands $s^{3,6,8,9}$. However, little is known about combat sports such as Brazilian jiu-jitsu (BJJ), which is a grappling sport with intermittent physical demands, highlighted by high-intensity movements interspersed by low-intensity actions, requiring both anaerobic and aerobic metabolism to maintain high performance during and between 
matches ${ }^{10}$. A previous study analyzed the hydro-electrolytic balance during BJJ during one day of simulated competition ${ }^{11}$. The author found increased serum Phosphorus (P) after the first match and decreased serum Calcium $(\mathrm{Ca})$ before successive matches, but no altered value for Chloride $(\mathrm{Cl})$, Sodium $(\mathrm{Na})$, Potassium $(\mathrm{K})$, Magnesium $(\mathrm{Mg})$, and Iron $(\mathrm{Fe})^{11}$. However, there is still no information related to chemical elements analysis involving BJJ athletes during a preparatory training period. Moreover, chemical elements of interest reported previously can be detected and modulated by exercise in saliva ${ }^{12,13}$.

The objective of this study was to investigate the levels of chemical elements in the saliva samples of BJJ athletes during a training period for competition. Identification of chemical elements profile during periods of training may help identify biomarkers for training monitoring and guidelines for nutritional interventions.

\section{Material and Method}

\subsection{Subjects}

Sixteen high-level BJJ athletes graded purple, brown, and black belts were invited to participate in the study. All the athletes were engaged in official competitions, at state and national levels, ruled by the International Brazilian Jiu-Jitsu Federation (IBJJF), with at least 6 years of BJJ practice. The exclusion criteria adopted were the presence of injuries, use of illicit drugs (anabolic hormones), use of anti-inflammatory drugs or vitamin supplements for at least 30 days before the study, use of continuous medication, smoking, and the presence of active dental caries and oral lesions. The oral health status was examined and supervised by a periodontologist to avoid any oral inflammatory process or active infection during the study period. The athletes were oriented not to change their habitual meals and not to include any additional nutritional supplement in their regular diet during the study period. The athletes were oriented to drink water ad libitum, rather than isotonic sports drinks, during the training period to avoid dehydration. The athletes were not submitted to dehydration or any weight loss strategy during the training period. Three athletes were excluded during the training period due to traumatic injury or the use of anti-inflammatory drugs. Twelve male athletes, aged 23 to 45 years, body mass $69.1 \pm 15.5 \mathrm{~kg}$ and height $1.76 \pm 0.05 \mathrm{~m}$, completed the training program and were included in the analysis.

The athletes were classified as light feather $(\mathrm{n}=1, \leq 64 \mathrm{~kg})$, feather $(\mathrm{n}=3, \leq 70 \mathrm{~kg})$, light $(\mathrm{n}=3, \leq 76 \mathrm{~kg})$, middle $(\mathrm{n}=2, \leq 82.3$ $\mathrm{kg})$, medium-heavy ( $\mathrm{n}=2, \leq 88.3 \mathrm{~kg}$ ), and super heavy ( $\mathrm{n}=1,>$ $100.5 \mathrm{~kg}$ ). The athletes were evaluated during the preparatory training period for the South American Championship, from October to November of 2015. All athletes were briefed on the procedures and purpose of the study and signed a written and informed term of consent to participate. The study procedures were approved by the institutional Ethics Committee in Research with Human Beings (n.2.078.585).
All the procedures have been carried out following the recommendations of the Declaration of Helsinki.

\subsection{Study design}

The athletes were submitted to one physical and one technical-tactical training session per day, for 5 days a week, during 7 uninterrupted weeks.

The saliva sampling was collected, before starting the training period (Pre), before the first training session of the fourth week, and at the eighth week (Post). Twenty-four hours before the sampling, the athletes were instructed not to perform any vigorous physical effort, to avoid alcoholic beverages and ergogenic supplements (including caffeine), and to respect a 12 -h period of fasting. The sample collections were performed with athletes at rest, before the first weekly training session, at the same hour to avoid circadian variation in saliva secretion and composition.

\subsection{Training program}

The athletes were submitted to one physical training session per day (5 times a week), lasting approximately 60 min, and one daily technical-tactical session per day (6 times a week), lasting $90 \mathrm{~min}$. A detailed description of the training schedule, monitoring training loads, and performance have been previously published ${ }^{14}$.

\subsubsection{Rating of perceived exertion of session}

Fifteen minutes after each physical and technical-tactical training session, the athletes provided an overall rating of perceived exertion (RPE) using Borg's CR-10 scale ${ }^{1}$. The athletes were previously familiarized with the procedure. The daily training load was calculated as the mean of physical and technical-tactical training sessions. The weekly training load was calculated as the mean of daily RPE reported during the training week.

\subsubsection{Saliva sampling}

Unstimulated whole saliva was collected at rest, between 08:00 a.m. and 10:00 a.m.h. They were instructed to spontaneously salivate into sterile graduated tubes for $2 \mathrm{~min}$. The saliva flow rate was determined by the volume $(\mathrm{mL})$ of saliva secreted per minute. The saliva samples were centrifuged at $10,000 \mathrm{~g}$, for 10 minutes to homogenize the sample and to precipitate mucins and cell debris. The supernatant saliva was immediately frozen at $-20{ }^{\circ} \mathrm{C}$, until the analysis.

\subsubsection{Total Reflection X-Ray Fluorescence}

The X-ray fluorescence measurements were performed using a TXRF system type S2 Picofox (Bruker Corporation, Berlin, Germany), and evaluated by SPECTRA software (Bruker, Berlin, Germany). The S2 Picofox system consists of an X-ray tube with a Molybdeniummtarget and a silicon drift detector with a resolution of $150 \mathrm{eV}$. The voltage, current, and 
electric power used in the X-ray tube were $50 \mathrm{kV}, 602 \mu \mathrm{A}$, and $30 \mathrm{~W}$, respectively. Ten $\mu \mathrm{L}$ of saliva were kept on acrylic discs and put into an oven at a maximum temperature of $55^{\circ} \mathrm{C}$ for 30 minutes to dry the samples. After drying, each sample was irradiated for $500 \mathrm{~s}$ and read in triplicate, discounting background values. The background value of each disc was read before placing the samples and the standardd. The system was calibrated with certified water and $10 \mu \mathrm{L}$ of Gallium (cat. 170319, Merck Millipore, Darmstadt, Germany). For each sample, the test-retest reliability was performed three times and was higher than $10 \%$ for each chemical element. Elemental detection varies from aluminum $(Z=13)$ to yttrium $(Z=39)$ for $K$ series radiation, with higher atomic numbers identified by the $\mathrm{L}$ or $\mathrm{M}$ series. The system accuracy was checked before each experiment with standard solutions certified and recommended by the manufacturer.

\subsection{Statistical analysis}

The Shapiro-Wilk test was applied to evaluate the normal distribution. Data with Gaussian distribution were described as mean and standard deviation and the differences were tested with a one-way analysis of variance (ANOVA one-way) with repeated measures and Tukey's tests. Nonparametric data were described as median and $25 \%$ to $75 \%$ interquartile range and differences among the moments were tested with Friedman and Dunn's tests. Differences were considered significant if $\mathrm{p}<0.05$. The effect size was calculated following the classification: $<0.20$ (small); $>0.20$ until 0.80 (medium) and $\geq 0.80$ (large), in order to identify the magnitude of changes in ion concentrations amongn different time points. Statistical power achieved $80 \%$ for differences between Pre to 4 weeks of macroelements in saliva. Statistical analysis was performed in GraphPad Prisma v.5.01 (GraphPad Software, San Diego, CA, USA) and G*Power software v. 3.1.9.6. (Franz Faul, University of Dusseldorf, Germany).

\section{Results and Discussion}

Weeks 1 to 4 were considered as having intensified training loads in physical training sessions (Figure 1). The saliva flow rate was reduced after 4 weeks $(0.7 \pm 0.2 \mathrm{ml} / \mathrm{min}, \mathrm{p}<0.05)$ of intensified training compared with Pre $(0.8 \pm 0.4 \mathrm{ml} / \mathrm{min})$ and Post $(0.9 \pm 0.3 \mathrm{ml} / \mathrm{min})$ values.

Figure 1 - Mean and standard deviation of daily Rating of Perceived Exertion (RPE) of Physical and Technical-tactical training sessio
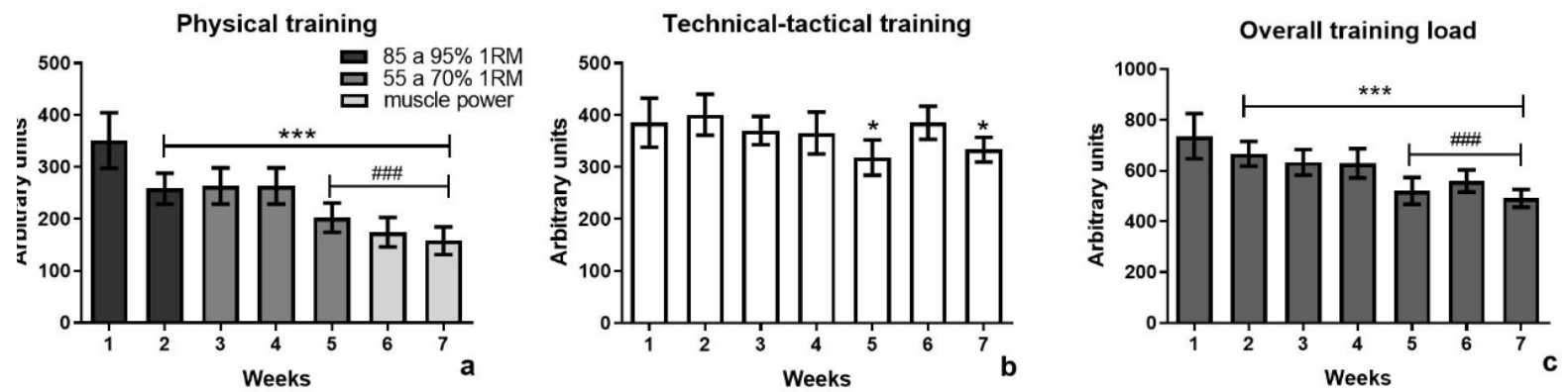

*** $\mathrm{p}<0.005$ in relation to week 1 ; ${ }^{\# \#} \mathrm{p}<0.005$ in relation to weeks $1,2,3,4 ; * \mathrm{p}<0.05$ in relation to week 2 ; Tukey's test

Source: The authors.

All the saliva samples presented phosphorus (P), Sulfur (S), Chlorine (Cl), Potassium (K), Calcium (Ca), Bromine $(\mathrm{Br})$, and Rubidium $(\mathrm{Rb})$ at Pre, 4 weeks, and Post time pointshe Manganese ( $\mathrm{Mn})$ was detected in $8(66.6 \%)$ samples at Pre, $3(25 \%)$ at 4 weeks, and $5(41.6 \%)$ at Posthe Titanium (Ti) was detected in $4(33.3 \%)$ samples at Pre and 4 weeks, and 3 (25\%) samples at Posthe Iron (Fe) was detected in $10(83.3 \%)$ samples at Pre and all samples at
4 weeks and Posthe Copper $(\mathrm{Cu})$ was detected in $9(75 \%)$ samples at Pre, $4(33.3 \%)$ at 4 weeks, and $5(41.6 \%)$ at Posthe $\mathrm{Zn}$ was below the detection limit only in one $(8.3 \%)$ sample at Post.

Salivary concentrations of macroelements $\mathrm{S}, \mathrm{P}, \mathrm{Ca}, \mathrm{Cl}$, and $\mathrm{K}$ were presented in figure 2 . $\mathrm{Cl}$ and $\mathrm{K}$ significantly decreased at week 4 (Figure 2). The $\mathrm{K}$ concentration remained at low levels at Post (Figure 2).

Figure 2 - Median and interquartile range ( 25 to $45 \%$ ) of salivary concentration of macroelements in BJJ athletes ( $\mathrm{n}=12$ )
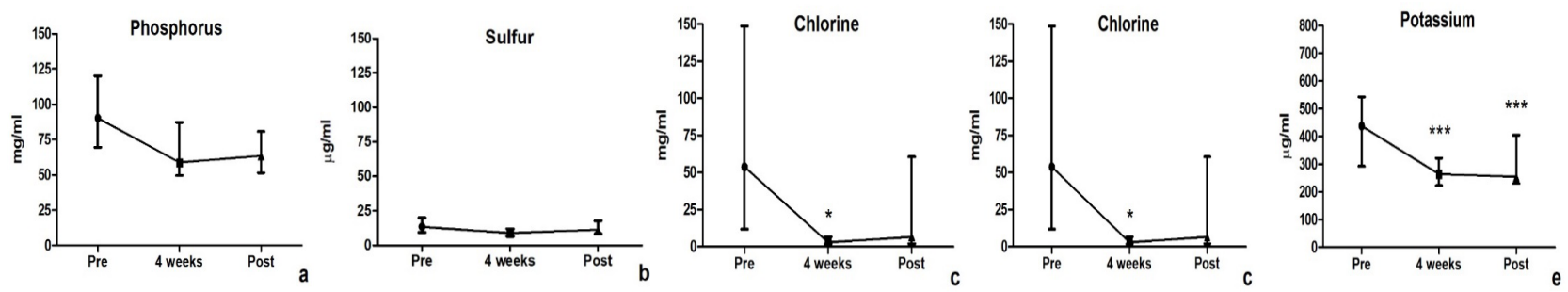

$* P<0.05$ and $* * * P<0.005$ in relation to Pre value, Friedman and Dunn's tests.

Source: The authors. 
The salivary levels of the trace elements $\mathrm{Mn}, \mathrm{Cu}, \mathrm{Br}$, and $\mathrm{Rb}$ significantly decreased at 4 weeks (Figure 3 ). Thf $\mathrm{Cu}$ and $\mathrm{Rb}$ concentrations remained decreased at Post moment (Figure 3). Mn was not detected in two athletes and $\mathrm{Cu}$ in three subjects at any time of analysis (figure 3). Ti ions were present in different subjects at different moments and were not included in the statistical analysis.

Figure 3 - Median and interquartile range (25 to $45 \%$ ) of salivary concentration of trace elements in BJJ athletes $(n=12), M n(n=10)$ and $\mathrm{Cu}(\mathrm{n}=9)$
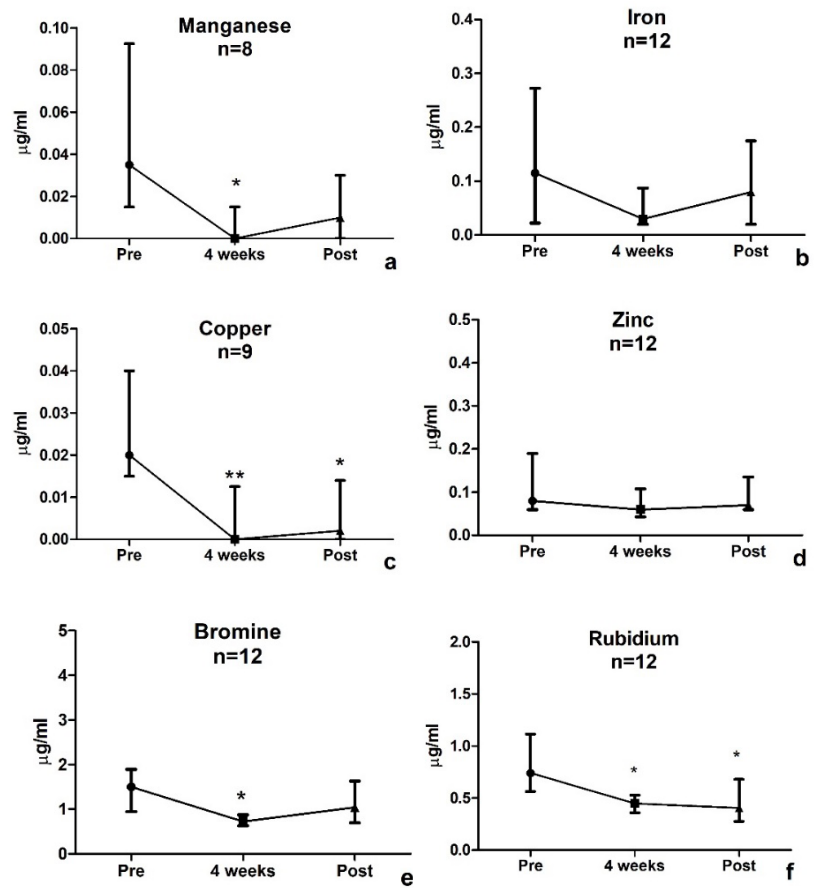

$* P<0.05$ and $* * P<0.01$ in relation to Pre value, Friedman and Dunn's tests.

Source: The authors.
The secretion rate of salivary elements was calculated as the rate of ions secreted per $\min (\mu \mathrm{g} / \mathrm{min})$. The saliva secretion rate of ions presented a similar behavior to salivary ion concentration, except for P (Table 1).

Table 1 - Ion secretion rates in saliva ( $\mu \mathrm{g} / \mathrm{min})$

\begin{tabular}{|l|c|c|c|}
\hline & Pre & 4 Weeks & Post \\
\hline $\mathbf{P}$ & $62.1[51.6-134.6]$ & $43.1[33.0-60.1]^{*}$ & $63.6[46.3-87.5]$ \\
\hline $\mathbf{S}$ & $13.1[5.3-19.1]$ & $6.1[3.6-11.3]$ & $10.5[6.5-16.1]$ \\
\hline $\mathbf{C l}$ & $25.5[8.2-128.4]$ & $3.5[1.1-5.6]^{* *}$ & $7.5[1.7-50.8]$ \\
\hline $\mathbf{K}$ & $273.5[211-441.8]$ & $219.7[131.7-238.4]^{*}$ & $225.3[202.9-400.7]$ \\
\hline $\mathbf{C a}$ & $11.8[8.7-20.3]$ & $7.6[5.4-12.2]$ & $13.4[7.6-18.8]$ \\
\hline $\mathbf{M n}$ & $0.03[0.01-0.08]$ & $0.0[0.0-0.01]^{*}$ & $0.009[0.0-0.02]$ \\
\hline $\mathbf{F e}$ & $0.11[0.01-0.25]$ & $0.02[0.01-0.04]$ & $0.04[0.02-0.18]$ \\
\hline $\mathbf{C u}$ & $0.01[0.01-0.03]$ & $0.0[0.0-0.01]^{*}$ & $0.003[0.0-0.01]$ \\
\hline $\mathbf{Z n}$ & $0.08[0.03-0.14]$ & $0.05[0.02-0.07]$ & $0.08[0.04-0.09]$ \\
\hline $\mathbf{B r}$ & $1.25[0.45-1.82]$ & $0.48[0.33-0.69]^{*}$ & $0.97[0.67-1.46]$ \\
\hline
\end{tabular}
Note: data are expressed by median and percentiles $25 \%$ and $75 \% ; \mathrm{P}=$ phosphorus; $\mathrm{S}=$ sulfur $; \mathrm{Cl}=$ chlorine $\mathrm{K}=$ potassium; $\mathrm{Ca}=$ calcium; $\mathrm{Zn}=$ zinc; $\mathrm{Br}=$ bromine; $* \mathrm{P}<0.05, * * \mathrm{P}<0.01$ in relation to Pre. Dunn's test. Source: Resource data.

The effect sizes of differences from Pre to 4 weeks revealed medium to large effects, except for $\mathrm{Zn}$. Although no statistical significance was detected in $\mathrm{P}$ concentration, the effect sizes for differences from Pre to 4 weeks and Post were considered large. The mean difference from Pre to Post demonstrated that most chemical elements, except $\mathrm{P}$ and $\mathrm{Cu}$, returned to basal levels. The $\mathrm{Br}$ ion presented a large effect from 4 weeks to Post, suggesting a faster return to basal levels (Table 2)

Table 2 - Cohen's effect sizes for differences in ion concentrations among Pre, Mid, and Post

\begin{tabular}{|c|c|c|c|c|c|c|}
\hline & $\begin{array}{c}\% \Delta \text { Pre - } \\
\text { week } 4\end{array}$ & d (ES) & $\begin{array}{c}\% \Delta \\
\text { Pre-post }\end{array}$ & d (ES) & $\% \Delta$ week 4 - Post & D (ES) \\
\hline $\mathbf{P}$ & $-26.5 \pm 4.9$ & 0.95 (Large) & $-48.8 \pm 4.5$ & -0.85 (Large) & $26.8 \pm 35.4$ & 0.35 (Small) \\
\hline $\mathbf{S}$ & $-88.8 \pm 1.6$ & 0.81(Large) & $-36.4 \pm 55.4$ & 0.40 (Small) & $87.3 \pm 10.4$ & $-0.70($ Large $)$ \\
\hline Cl & $-69.4 \pm 4.4$ & 0.82 (Large) & $-23.5 \pm 54.8$ & 0.52 (Medium) & $55.4 \pm 36.8$ & -0.45 (Small) \\
\hline $\mathbf{K}$ & $-29.0 \pm 29.5$ & 0.77 (Medium) & $-71.1 \pm 80.8$ & $0.42($ Small $)$ & $-4.1 \pm 16.4$ & -0.69 (Medium) \\
\hline $\mathrm{Ca}$ & $6.6 \pm 94.0$ & 0.68(Medium) & $-35.9 \pm 81.0$ & -0.11 (Trivial) & $-89.8 \pm 425$ & -0.62 (Medium) \\
\hline $\mathbf{F e}$ & $-26.5 \pm 125$ & 1.16(Large) & $-157 \pm 224$ & 0.47(Small) & $-471.9 \pm 454$ & 0.76(Medium) \\
\hline $\mathrm{Cu}$ & $-50.2 \pm 37.3$ & 1.08(Large) & $-373 \pm 232$ & 0.93(Large) & $78.8 \pm 25.1$ & $0.30($ Small $)$ \\
\hline Zn & $43.6 \pm 181.2$ & 0.15 (Trivial) & $-39.4 \pm 100.8$ & -0.07 (Trivial) & $-100 \pm 132.5$ & 0.10 (Trivial) \\
\hline $\mathrm{Br}$ & $-79.9 \pm 31.5$ & 1.06(Large) & $-1491 \pm 634$ & 0.27 (Trivial) & $14.6 \pm 68.7$ & $-1.25($ Large $)$ \\
\hline
\end{tabular}

Note: $\mathrm{P}=$ phosphorus; $\mathrm{S}=$ sulfur; $\mathrm{Cl}=$ chlorine; $\mathrm{K}=$ potassium; $\mathrm{Ca}=$ calcium; $\mathrm{Zn}=$ zinc; $\mathrm{Br}=$ bromine; in order to verify the effect size's classification, please, see the methods.

Source: Resource data.

Table 3 demonstrates the correlation among the salivary chemical concentrations at Pre, 4 weeks, and Post with mean session RPE reported in the intensified (weeks 1 to 4 ) and tapering periods (weeks 5 to 7). Reduced S concentration at 4 weeks was negatively correlated to high training load in weeks 1 to 4 (Table 3). 
Table 3 - Spearman correlation test of salivary ion concentrations and mean daily RPE reported in a period of intensified training (Weeks 1 to 4) and non-intensified training (Weeks 5 to 7)

\begin{tabular}{|c|c|c|c|c|}
\hline Ion $(\boldsymbol{\mu g} / \mathbf{m L})$ & Pre & \multicolumn{2}{|c|}{ Fourth Week } & Post \\
\hline & $\begin{array}{c}\text { RPE } \\
\text { Weeks 1 to 4 } \\
\text { (intensified training load) }\end{array}$ & $\begin{array}{c}\text { RPE } \\
\text { Weeks 1 to 4 } \\
\text { (intensified training load) }\end{array}$ & $\begin{array}{c}\text { RPE } \\
\text { Weeks 5 to 7 } \\
\text { (tapering) }\end{array}$ & $\begin{array}{c}\text { RPE } \\
\text { Weeks 5 to 7 } \\
\text { (tapering) }\end{array}$ \\
\hline $\mathrm{P}$ & $\mathrm{r}=-0.25 \mathrm{p}=0.45$ & $\mathrm{r}=-0.50 \mathrm{p}=0.12$ & $\mathrm{r}=-0.46 \mathrm{p}=0.15$ & $\mathrm{r}=-0.14 \mathrm{p}=0.67$ \\
\hline $\mathrm{S}$ & $\mathrm{r}=0.16 \mathrm{p}=0.63$ & $\mathrm{r}=\mathbf{- 0 . 5 6} \mathbf{p}=\mathbf{0 . 0 5}$ & $\mathrm{r}=-0.54 \mathrm{p}=0.08$ & $\mathrm{r}=0.00 \mathrm{p}=0.99$ \\
\hline $\mathrm{Cl}$ & $\mathrm{r}=-0.16 \mathrm{p}=0.63$ & $\mathrm{r}=0.02 \mathrm{p}=0.94$ & $\mathrm{r}=-0.09 \mathrm{p}=0.79$ & $\mathrm{r}=-0.18 \mathrm{p}=0.59$ \\
\hline $\mathrm{K}$ & $\mathrm{r}=-0.14 \mathrm{p}=0.67$ & $\mathrm{r}=0.09 \mathrm{p}=0.79$ & $\mathrm{r}=-0.27 \mathrm{p}=0.42$ & $\mathrm{r}=-0.10 \mathrm{p}=0.77$ \\
\hline $\mathrm{Ca}$ & $\mathrm{r}=0.26 \mathrm{p}=0.43$ & $\mathrm{r}=-0.01 \mathrm{p}=0.96$ & $\mathrm{r}=-0.26 \mathrm{p}=0.42$ & $\mathrm{r}=-0.24 \mathrm{p}=0.38$ \\
\hline $\mathrm{Mn} *$ & $\mathrm{r}=-0.04 \mathrm{p}=0.90$ & - & - & - \\
\hline $\mathrm{Fe}$ & $\mathrm{r}=0.44 \mathrm{p}=0.20$ & $\mathrm{r}=-0.42 \mathrm{p}=0.20$ & $\mathrm{r}=-0.38 \mathrm{p}=0.24$ & $\mathrm{r}=-0.45 \mathrm{p}=0.15$ \\
\hline $\mathrm{Cu} *$ & $\mathrm{r}=-0.23 \mathrm{p}=0.51$ & - & - & - \\
\hline $\mathrm{Zn}$ & $\mathrm{r}=0.13 \mathrm{p}=0.70$ & $\mathrm{r}=-0.26 \mathrm{p}=0.41$ & $\mathrm{r}=-0.29 \mathrm{p}=0.38$ & $\mathrm{r}=-0.13 \mathrm{p}=0.69$ \\
\hline $\mathrm{Br}$ & $\mathrm{r}=0.07 \mathrm{p}=0.83$ & $\mathrm{r}=0.29 \mathrm{p}=0.33$ & $\mathrm{r}=-0.03 \mathrm{p}=0.92$ & $\mathrm{r}=-0.09 \mathrm{p}=0.80$ \\
\hline $\mathrm{Rb}$ & $\mathrm{r}=-0.26 \mathrm{p}=0.43$ & $\mathrm{r}=-0.18 \mathrm{p}=0.39$ & $\mathrm{r}=-0.42 \mathrm{p}=0.19$ & $\mathrm{r}=-0.18 \mathrm{p}=0.59$ \\
\hline
\end{tabular}

Note: $\mathrm{P}=$ phosphorus; $\mathrm{S}=$ sulfur; $\mathrm{Cl}=$ chlorine; $\mathrm{K}=$ potassium; $\mathrm{Ca}=$ calcium; $\mathrm{Zn}=$ zinc; $\mathrm{Br}=$ bromine; $*=\mathrm{Mn}$ and $\mathrm{Cu}$ were not included in the analysis due to the small sample size with detected levels of these ions.

Source: Resource data.

The main finding of the present study demonstrated that chemical element concentrations in saliva samples are modulated by training loads in BJJ. The use of TXRF to detect these changes allowed quantification of the variations in elementary saliva concentrations suggesting it is a suitable method for monitoring salivary electrolytic balance in highlevel BJJ athletes. The TXRF of saliva samples demonstrated that the concentration of some essential $(\mathrm{Cl}$ and $\mathrm{K})$ and trace elements $(\mathrm{Mn}, \mathrm{Cu}, \mathrm{Br}, \mathrm{Rb})$ were significantly reduced after a period of intense training, except $\mathrm{Zn}$. A previous work of our research groups demonstrated that saliva is an easy sample and non-invasive method to monitor physiological responses to intensified training periods, such as anabolic/ stress balance and immunity ${ }^{14}$. Another study demonstrated that several salivary chemical elements were detected (P, S, $\mathrm{Cl}, \mathrm{K}, \mathrm{Ca}, \mathrm{Fe}, \mathrm{Zn}, \mathrm{Br}$, and $\mathrm{Rb}$ ) in saliva and modulated by physical efforts ${ }^{2}$. Moreover, the salivary levels of $\mathrm{K}, \mathrm{Zn}, \mathrm{S}, \mathrm{Cl}$, $\mathrm{P}$, and $\mathrm{Mn}$ presented a correlation with serum concentration, meaning they can be monitored by saliva instead of invasive blood sampling ${ }^{12}$

The use of TXRF may be an alternative to other analytical methods since it can be used to screen a large range of chemical elements in saliva, is easy to handle, and allows faster analysis ${ }^{16}$. Besides, the use of TXRF may reduce the risk of the operator's technical error and contamination since it does not require sample preparation. For instance, several ions of interest in sports sciences may be detected by TXRF in a simple procedure ${ }^{12,16}$. Considering that some trace elements and macroelements are modulated in peripheral blood during physical exercise, and some have been demonstrated to be selectively secreted and reabsorbed by salivary glands, saliva analysis through TXRF may be a promising method to monitor the health status and athletes' salivary ionsn balancs.

Salivary ions are involved in mineralizing enamel and the saliva buffer capacita. Saliva secretion is under the control of oral stimulus, the autonomic nervous system, endocrine system, plasma composition, stress, and hydration ${ }^{17-19}$. During saliva secretion, acinar cells release proteins, $\mathrm{Cl}^{-}, \mathrm{Na}^{+}$, and $\mathrm{K}^{+}$into the gland lumen. The ions transport induces the movement of water from plasma to hypertonic saliva ${ }^{17,18}$. The ions exchange also occurs in striated ducts, increasing $\mathrm{Ca}, \mathrm{P}$, and $\mathrm{K}$ secretion and changing saliva composition into a hypotonic solution ${ }^{17}$. The autonomic nervous system can modulate the ions and proteins secretion stimulating water ion transport from the blood through the acinar gland, or by stimulated active transport through the secretory cells ${ }^{17,20}$. Considering that exercise can modulate the saliva secretion rate by the autonomic nervous system ${ }^{21,22}$, some alterations in electrolyte composition were expected. Moreover, some electrolytes may be transported by water flow into saliva, and consequently, resemble serum concentration, and others may be actively secreted by stimulation of the autonomic nervous system $^{17,20}$.

Increased serum levels of P may be observed in athletes at rest and significantly increase after physical efforts ${ }^{8,9223}$. On the other hand, a previous study demonstrated that P salivary secretion was significantly down modulated after a bout of intense exercise in futsal players ${ }^{5}$. This suggests that intense physical efforts modulate $\mathrm{P}$ concentration in body fluids. Monitoring serum $\mathrm{P}$ is important since it was associated with muscle damage and impaired renal function and correlated with creatine kinase (CK) and creatinine levels, respectively9. 
In the present study, lower levels of $\mathrm{P}$ after 4 weeks and at Post were unexpected results, since high loads, as observed in BJJ athletes training and simulated matches, increase the serum biomarkers of muscle damage, and renal dysfunction in elite endurance and resistance athletes ${ }^{2,10,23}$. Besides, a previous study involving a BJJ simulated competition (4 matches of 10min) showed an increase in serum $P$ concentrations in the first and fourth match ${ }^{11}$. However, the $\mathrm{P}$ concentration in saliva is much higher than serum concentration and can be modulated by the active transport in salivary striated ducts ${ }^{17,22,24}$. Under high training loads and stress, sympathetic activity is increased and can reduce the electrolytic transport and water content in saliva $^{21,25,26}$. It may contribute to reduced flow rate and ionsn concentration after the intensive training period (4 weeks). In relation to training loads, the levels of $\mathrm{P}$ at 4 weeks presented an inverse and moderate correlation with mean RPE reported during the intensive training period (weeks 1 to 3 ) and weeks 4 to 7 . The results suggest that $\mathrm{P}$ could be detected in high concentrations by TXRF in saliva and is down modulated by higher BJJ training loads.

Sulfur-containing compounds, such as thiol-basic antioxidants and sulfur amino acids, are involved in the aerobic metabolism, lipid profile, antioxidant status, and resistance to muscle fatigue ${ }^{1,27,28}$. A study in futsal athletes did not find significant alterations in salivary $\mathrm{S}$ secretion after a bout of exercise $\mathrm{e}^{5}$. In the present study, no statistical differences in $\mathrm{S}$ were observed at different training periods; however, the effect size and correlation suggest salivary $\mathrm{S}$ levels decreased after intensive training. Although S levels could be detected in high concentrations in saliva, it may not be a suitable biomarker for monitoring training status using whole saliva samples. For instance, sulfur can be present in the oral cavity due to the production of sulfur-containing compounds by local anaerobic bacteria associated with periodontal disease and halitosis, instead of secretion by salivary glands ${ }^{29,30}$. In the present study, caution was taken to avoid any oral condition (active caries, gingivitis, and periodontal disease) that could increase oral biofilm with sulfur-containing bacteria.

$\mathrm{Cl}$ and $\mathrm{K}$ presented a positive moderate correlation in the saliva samples ${ }^{31}$. Indeed,d a large effect was found in $\mathrm{Cl}$ and $\mathrm{K}$ changes after 4 weeks and Post moments. This behavior is different from that observed in a BJJ simulated competition, in which there were no changes in serum $\mathrm{K}$ concentration ${ }^{11}$. In this sense, $\mathrm{Cl}$ is secreted by salivary glands under stimulation from the parasympathetic nervous system 17,32. So, increased salivary $\mathrm{Cl}$ secretion may be observed when athletes were at rest and physically recovered. Recovery is associated with high parasympathetic tonus ${ }^{33}$, whereas periods of intensified training decreased the parasympathetic tonus and increased the physiological stress ${ }^{14,34}$ Indeed, our previous study found a high degree of stress and under-recovery in BJJ athletes at 4 weeks, compared to Pre ant Post moments ${ }^{14}$, which may contribute to impaired $\mathrm{Cl}$ secretion.

During saliva secretion, chlorine channels located on acinar cells are open and $\mathrm{Cl}^{-}$is released into the glandular lumen $^{32}$. The ionic gradient induced by $\mathrm{Cl}$ ions stimulates the movement of $\mathrm{Na}^{+}$and $\mathrm{K}^{+}$into the luminal compartment and the movement of water due to increased osmolarity ${ }^{17,32}$. Later, the excess of $\mathrm{Cl}$ and $\mathrm{Na}$ are removed in striated ducts, whereas $\mathrm{K}$, $\mathrm{Ca}$, and $\mathrm{P}$ are secreted by active transport ${ }^{3}$. As described earlier, the increased training load and stress were highlighted by increased sympathetic activation and parasympathetic withdrawal ${ }^{20,21,25}$, which might be accounted for reduced salivary flow rate and lower levels of $\mathrm{Cl}$ and $\mathrm{K}$ in saliva during the intense training period. Other authors described low levels of salivary $\mathrm{K}$ found in young female fencers and field hockey athletes in relation to control subjects ${ }^{4}$. The authors correlated the low level of salivary $\mathrm{K}$ to increased loss of the element due to training since athletes presented increased concentrations of $\mathrm{K}$ in hair samples ${ }^{4}$.

Manganese has been detected in low concentrations in saliva samples and was significantly redud by at 4 weeks. However, Mn ions were not detected in all the athlet The Mn is related to the antioxidant status, and its serum levels seemed not to be affected by a single bout of intense exercise ${ }^{1,5}$. Howev,ved a strong negative correlation was observed between $\mathrm{Mn}$ in serum and salivary samples in futsal athletes submitted to acute efforts ${ }^{5}$. This suggests that monitoring Mn saliva levels could be associated with overall Mn balance in response to training loads.

Iron deficiency is a common feature in trained athletes, especially in aerobic training ${ }^{6}$. A high frequency of episodes of serum Fe deficiency has been reported in male and female middle and long-distance runners $(31.3 \%$ and $55.6 \%)$ and triathletes ( $37.5 \%$ and $60 \%$, respectively $)^{35}$, claiming attention to monitor this microelement. An acute bout of high-intensity interval running increased serum iron levels in long-distance runners and triathletes ${ }^{7}$ while no differences in salivary and serum levels could be detected in futsal athletes ${ }^{5}$. A study in female long-distance runners during a period of lowintensity training and after a period of high-intensity loads demonstrated no significant changes in serum iron levels ${ }^{37}$. Interestingly, ion of carbohydrate diet concentration reduced RPE and maintained high serum Fe levels up to $3 \mathrm{~h}$ after the exercise in runners ${ }^{36}$. In BJJ athletes, no alterations in serum $\mathrm{Fe}$ in a simulated competition (4 matches) were found ${ }^{11}$. I found a negative moderate correlation was found between RPE and Fe levels. A large effect was observed from Pre to fourth week, however, it did not reach statistical significance due to variability amoetween athletes. Further studies are necessary to investigate the association of Fe with individual RPE.

$\mathrm{Zn}$ is also associated with anti-oxidant levels in athletes and may be altered by exercise intensity, energy metabolism, and nutritional status ${ }^{1,7}$. In trained cyclists and futsal athletes, the exercise intensity presented a weak correlation with $\mathrm{Zn}$ levels ${ }^{5,38}$. Another study in basketball players demonstrated that a single session of high-intensity exercise could decrease 
the serum $\mathrm{Zn}$ levels ${ }^{7}$. The $\mathrm{Zn}$ levels were positively correlated with antioxidant defense (levels of $\mathrm{Cu}-\mathrm{Zn}$ superoxide dismutase enzyme) and lipid profile ${ }^{7}$. Although $\mathrm{Zn}$ is an important microelement ion of biological processes regulation related to anti-inflammatory and energy metabolisms, its values were not altered at different time points and did not correlate with the RPE of BJJ athletes.

Another important element with anti-oxidant and antiinflammatory effects in athletes' blood is $\mathrm{Cu}^{1}$. A week of intense training decreased the serum $\mathrm{Cu}$ levels in elite basketball players ${ }^{6}$. In the present study, low levels of $\mathrm{Cu}$ were observed in BJJ athletes after 4 weeks of intense training and during Post, suggesting that training loads influenced the salivary $\mathrm{Cu}$ secretion. However, $\mathrm{Cu}$ ions were not detected in all the saliva samples. In the present study, caution was taken not to include subjects with active caries, since salivary $\mathrm{Cu}$ levels may be increased in patients with active caries ${ }^{39}$.

$\mathrm{Br}$ also presented decreased levels in saliva after intense training. It was observed that salivary levels of $\mathrm{Br}$ increased in proportion to serum concentration ${ }^{40}$, suggesting saliva may be used to monitor Br status. However, low levels of salivary $\mathrm{Br}$ detected at 4 weeks was corrrelate with RPE. The exact mechanism of salivary $\mathrm{Br}$ secretion and its biological effects in the oral cavity and exercise is not clear. The use of $\mathrm{Br}$ as a biomarker for training seems not to be a reliable marker of cumulated training load and fatigue.

The levels of $\mathrm{Rb}$ are also affected by training and did not return to basal levels atst. The $\mathrm{Rb}$ may be an interesting biological marker for monitoring BJJ athletes, a sport with high demand for an anaerobic system. A study in athletes demonstrated that anaerobic and aerobic-anaerobic athletes presented increased levels of serum $\mathrm{Rb}$ when compared to non-athletes and athletes with modalities with elevated aerobic demand ${ }^{3}$. The salivary levels of $\mathrm{Rb}$ are 30 folds enriched concerning serum levels, suggesting it is actively transported by the salivary glands ${ }^{40}$. The present results suggest that salivary $\mathrm{Rb}$ is down modulated by exercise and correlated to the persistence of increased RPE during the final of four training weeks.

Based on results, the use of TXRF to detect chemical elements content in saliva may be advantageous over other analytical methods, since saliva sampling is a non-invasive method, and the samples do not require preparation and are easily and quickly handled by the operator. However, it is relevant to highlight that this study did not control the nutritional intake, and future studies should perform this control since diet directly influences the ion concentrations in the body. Finally, new longitudinal studies with the control of feeding, hydration, weight loss and regain weight in combat sports may be conducted to confirm the relationship of salivary $\mathrm{Cl}, \mathrm{K}, \mathrm{P}, \mathrm{S}, \mathrm{Fe} \mathrm{Mn}, \mathrm{Cu}, \mathrm{Br}, \mathrm{Rb}$ with training loads. Considering that some chemical elements $(\mathrm{Mn}, \mathrm{Cl}$, and $\mathrm{K}$ ) present correlation with serum levels ae were modulated by a period of intense training loads, saliva samples could be used to screen these elements by a non-invasive method and their relationship with fatigue or performance. Other elements of interest, such as $\mathrm{Cu}, \mathrm{Br}$, and $\mathrm{Mn}$ can be supplemented by diet and future studies should investigf with saliva monitoring may be helpful in nutritional screening and prescribing. One limitation of the study was that it was not possible to standardirdized nutritional intake since athletes follow their dietary prescription accdingly to the recommendations of their nutritionists, in preparation for an important championship.

\section{Conclusion}

It was concluded that salivary chemical element concentration was down modulated by a period of intense training load, demonstrating a large effect, except for $\mathrm{Zn}$. Nevertheless, $\mathrm{K}$ and $\mathrm{Cl}$ may be altered due to changes in salivary flow rate. $\mathrm{P}, \mathrm{S}, \mathrm{Fe}$, and $\mathrm{Rb}$ seem to be feasible biomarkers for monitoring training loads since their levels were differently modulated after a period of intense training, presenting large effects of concentration after a period of intense training in comparison to lower training weeks and a moderate correlation with the RPE method.

\section{Acknowledgments}

The author A.C.Z. received a grant from the Coordination of Improvement of High Education Personnel - CAPES (1763037). The authors would like to thank Master Vinicius Cesare Modernel Canevari (Magoo) for his technical assistance and permission to investigate the athletic team undereir his training and coaching (Magoo Brazilian Jiu-Jitsu Team).

\section{References}

1. Speich M, Pineau A, Ballereau F. Minerals, trace elements and related biological variables in athletes and during physical activity. Clin Chim Acta 2001;312(1-2):1-11.

2. Jablan J, Inic S, Stosnach H, Hadziabdic MO, Vujic L, Domijan AM. Level of minerals and trace elements in the urine of the participants of mountain ultra-marathon race. J Trace Elem Med Biol 2017;41:54-9. doi: 10.1016/j. jtemb.2017.02.004

3. Maynar M, Llerena F, Grijota FJ, Alves J, Robles MC, Bartolome I, et al. Serum concentration of several trace metals and physical training. J Int Soc Sports Nutr 2017;14:19. doi: 10.1186/s12970-017-0178-7

4. Nabatov AA, Troegubova NA, Gilmutdinov RR, Sereda AP, Samoilov AS, Rylova NV. Sport- and sample-specific features of trace elements in adolescent female field hockey players and fencers. J Trace Elem Med Biol 2017;43:33-7. doi: 10.1016/j.jtemb.2016.11.002

5. Padoin S, de Freitas VH, Cleto DAM, Zeffa AC, Nakamura FY, Andrello AC, et al. Effects of Futsal Demands on Serum and Salivary Levels of Trace Elements and Minerals Detected by Total Reflection X-Ray Fluorescence. Biol Trace Eem Res. 2019. doi: 10.1007/s12011-019-01697-4

6. Wang L, Zhang J, Wang J, He W, Huang H. Effects of highintensity training and resumed training on macroelement and microelement of elite basketball athletes. Biol Trace Elem 
Res 2012;149(2):148-54. doi: 10.1007/s12011-012-9420-y

7. Zhao J, Fan B, Wu Z, Xu M, Luo Y. Serum zinc is associated with plasma leptin and $\mathrm{Cu}-\mathrm{Zn}$ SOD in elite male basketball athletes. J Trace Elem Med Biol 2015;30:49-53. doi: 10.1016/j.jtemb.2014.10.005

8. Karakukcu C, Polat Y, Torun YA, Pac AK. The effects of acute and regular exercise on calcium, phosphorus and trace elements in young amateur boxers. Clin Lab 2013;59(56):557-62.

9. Malliaropoulos N, Tsitas K, Porfiriadou A, Papalada A, P RA, Del Buono A, et al. Blood phosphorus and magnesium levels in 130 elite track and field athletes. Asian J Sports Med 2013;4(1):49-53.

10. Andreato LV, Julio UF, Panissa VL, Esteves JV, Hardt F, de Moraes SM, et al. Brazilian Jiu-Jitsu Simulated Competition Part I: Metabolic, Hormonal, Cellular Damage, and Heart Rate Responses. J Strength Cond Res 2015;29(9):2538-49. doi: 10.1519/JSC.0000000000000918

11. Andreato LV, Pastório EJ, Moraes SMFd, Esteves JVDC, Panissa VLG, Julio UF, et al. Hydroelectrolytic balance of Brazilian jiu-jitsu athletes during a simulated competition. Sport Scie Health 2016;12(2):183-8.

12. Padoin S, de Freitas VH, Cleto DAM, Zeffa AC, Nakamura FY, Andrello AC, et al. Effects of Futsal Demands on Serum and Salivary Levels of Trace Elements and Minerals Detected by Total Reflection X-Ray Fluorescence. Biol Trace Elem Res 2020;193(1):73-80. doi: 10.1007/s12011-019-01697-4

13. Andreato LV, Pastório EJ, Moraes SMFd, Esteves JVDC, Panissa VLG, Julio ÚF, et al. Hydroelectrolytic balance of Brazilian jiu-jitsu athletes during a simulated competition. Sports Scie Health 2016;12:183-8. doi: 10.1007/s11332-0160273-1

14. Campos F, Molina Correa JC, Canevari VCM, Branco BHM, Andreato LV, de Paula Ramos S. Monitoring Internal Training Load, Stress-Recovery Responses, and Immune-Endocrine Parameters in Brazilian Jiu-Jitsu Training. J Strength Cond Res 2020. doi: 10.1519/JSC.0000000000003507

15. Foster C, Florhaug JA, Franklin J, Gottschall L, Hrovatin LA, Parker S, et al. A new approach to monitoring exercise training. J Strength Cond Res 2001;15(1):109-15.

16. Poles AA, Jr., Balcao VM, Chaud MV, Vila M, Aranha N, Yoshida VMH, et al. Study of the elemental composition of saliva of smokers and nonsmokers by X-ray fluorescence. Appl Radiat Isot 2016;118:221-7. doi: 10.1016/j. apradiso.2016.09.007

17. Proctor GB. The physiology of salivary secretion. Periodontol 2000 2016;70(1):11-25. doi: 10.1111/prd.12116

18. Segal SK. Neuroscience meets salivary bioscience: An integrative perspective. Behav Neurosci. 2016;130(2):15675. doi: $10.1037 / \mathrm{bne} 0000141$

19. Villiger M, Stoop R, Vetsch T, Hohenauer E, Pini M, Clarys P, et al. Evaluation and review of body fluids saliva, sweat and tear compared to biochemical hydration assessment markers within blood and urine. Eur J Clin Nutr 2018;72(1):69-76. doi: 10.1038/ejen.2017.136

20. Proctor GB, Carpenter GH. Regulation of salivary gland function by autonomic nerves. Auton Neurosc 2007;133(1):318. doi: 10.1016/j.autneu.2006.10.006

21. Yoshino Y, Yamane A, Suzuki M, Nakagawa Y. Availability of saliva for the assessment of alterations in the autonomic nervous system caused by physical exercise training.
Arch Oral Biol 2009;54(11):977-85. doi: 10.1016/j. archoralbio.2009.07.012

22. Proctor GB, Carpenter GH. Salivary secretion: mechanism and neural regulation. Monogr Oral Sci 2014;24:14-29. doi: $10.1159 / 000358781$

23. Koch AJ, Pereira R, Machado M. The creatine kinase response to resistance exercise. J Musculoskelet Neuronal Interact 2014;14(1):68-77.

24. Tobey SL, Anslyn EV. Determination of inorganic phosphate in serum and saliva using a synthetic receptor. Org Lett 2003;5(12):2029-31. doi: 10.1021/o1034427x

25. Flatt AA, Esco MR, Nakamura FY, Plews DJ. Interpreting daily heart rate variability changes in collegiate female soccer players. J Sports Med Phys Fitness 2017;57(6):907-15. doi: 10.23736/S0022-4707.16.06322-2

26. Sartor F, Vailati E, Valsecchi V, Vailati F, La Torre A. Heart rate variability reflects training load and psychophysiological status in young elite gymnasts. J Strength Cond Res 2013;27(10):2782-90. doi: 10.1519/JSC.0b013e31828783cc

27. Elshorbagy AK, Valdivia-Garcia M, Graham IM, Palma Reis R, Sales Luis A, Smith AD, et al. The association of fasting plasma sulfur-containing compounds with BMI, serum lipids and apolipoproteins. Nutr Metab Cardiovasc Dis 2012;22(12):1031-8. doi: 10.1016/j.numecd.2011.01.008

28. Ferreira LF, Campbell KS, Reid MB. Effectiveness of sulfurcontaining antioxidants in delaying skeletal muscle fatigue. Med Sci Sports Exerc 2011;43(6):1025-31. doi: 10.1249/ MSS.0b013e3182019a78

29. Krespi YP, Shrime MG, Kacker A. The relationship between oral malodor and volatile sulfur compound-producing bacteria. Otolaryngol Head Neck Surg 2006;135(5):671-6. doi: 10.1016/j.otohns.2005.09.036

30. Mokeem SA. Halitosis: a review of the etiologic factors and association with systemic conditions and its management. J Contemp Dent Pract 2014;15(6):806-11.

31. Rehak NN, Cecco SA, Csako G. Biochemical composition and electrolyte balance of "unstimulated" whole human saliva. Clin Chem Lab Med 2000;38(4):335-43. doi: 10.1515/ CCLM.2000.049

32. Melvin JE. Chloride channels and salivary gland function. Crit Rev Oral Biol Med 1999;10(2):199-209.

33. Chen JL, Yeh DP, Lee JP, Chen CY, Huang CY, Lee SD, et al. Parasympathetic nervous activity mirrors recovery status in weightlifting performance after training. J Strength Cond Res 2011;25(6):1546-52. doi: 10.1519/JSC.0b013e3181da7858

34. Weippert M, Behrens M, Mau-Moeller A, Bruhn S, Behrens K. Relationship Between Morning Heart Rate Variability and Creatine Kinase Response During Intensified Training in Recreational Endurance Athletes. Front Physiol. 2018;9:1267. 10.3389/fphys.2018.01267

35. Coates A, Mountjoy M, Burr J. Incidence of Iron Deficiency and Iron Deficient Anemia in Elite Runners and Triathletes. Clin J Sport Med 2017;27(5):493-8. doi: 10.1097/ JSM.0000000000000390

36. Badenhorst CE, Dawson B, Cox GR, Laarakkers CM, Swinkels DW, Peeling P. Acute dietary carbohydrate manipulation and the subsequent inflammatory and hepcidin responses to exercise. Eur J Appl Physiol 2015;115(12):252130. doi: 10.1007/s00421-015-3252-3

37. Ishibashi A, Maeda N, Sumi D, Goto K. Elevated serum hepcidin levels during an intensified training period in well- 
trained female long-distance runners. Nutrients. 2017;9(3). doi: $10.3390 /$ nu9030277

38. Gonzalez-Haro C, Soria M, Lopez-Colon JL, Llorente MT, Escanero JF. Plasma trace elements levels are not altered by submaximal exercise intensities in well-trained endurance euhydrated athletes. J Trace Elem Med Biol 2011;25 Suppl 1:S54-8. doi: 10.1016/j.jtemb.2010.10.010
39. Watanabe K, Tanaka T, Shigemi T, Hayashida Y, Maki K. Mn and $\mathrm{Cu}$ concentrations in mixed saliva of elementary school children in relation to sex, age, and dental caries. J Trace Elem Med Biol 2009;23(2):93-9. doi: 10.1016/j.jtemb.2009.01.003

40. Olmez I, Gulovali MC, Gordon GE, Henkin RI. Trace elements in human parotid saliva. Biol Trace Eem Res. 1988; 17:259-70 